\title{
An evaluation of IRT neonatal analytical performance in AutoDELFIA ${ }^{\circledR}$
}

\author{
Avaliação do desempenbo analítico do IRT neonatal no equipamento AutoDELFIA ${ }^{\circledR}$
}

Raquel Weber'; Michele Pavan'; André Canto de Souza²; Simone Martins de Castro ${ }^{3}$

\begin{abstract}
Neonatal screening programs for cystic fibrosis (CF) usually consist of an immunoreactive trypsinogen assay. The objective of this study was to validate the AutoDELFIA ${ }^{\circledR}$ Neonatal immunoreactive trypsinogen kit. We carried out a comparative study between two equipments. The following results were yielded: random error $=26.6 \%$, systematic error $=4.95 \%$ and analytical error $=31.5 \%$. Several factors contributed to the assay variations in dried blood spot, namely chromatographic, hematocrit and total blood volume effects. These factors should be taken into account in the assessment of validation results. The studied kit can be deployed in neonatal screening routine.
\end{abstract}

Key words: neonatal screening; cystic fibrosis; validation studies; trypsinogen.

\section{INTRODUCTION}

Cystic fibrosis (CF) is the most frequent life-limiting autosomal recessive disorder in Caucasian children ${ }^{(12)}$. Each year, approximately 1,000 persons receive a diagnosis of $\mathrm{CF}$ in the United States $^{(3)}$. In the south of Brazil, the estimated prevalence is $1 / 2,500$ live births $^{(13)}$.

It is caused by mutations in 2 alleles of the gene encoding for the CF transmembrane conductance regulator (CFTR) protein, which acts mainly as a 3'-5'-cyclic adenosine monophosphate (cAMP) activated chloride channel ${ }^{(3,12)}$. Although more than 1,000 different molecular abnormalities have been described in CF individuals, a single common mutation (delF508) accounts for two thirds of all CF alleles worldwide. This mutation is particularly frequent in persons of northern European ancestry, who also have the highest rates of CF, although it is less common among persons of other ancestries.

Classic CF is a multisystem disease characterized by elevated chloride concentrations in sweat, fat maldigestion due to pancreatic exocrine insufficiency, and chronic bacterial infection in the airways, which leads to terminal respiratory failure ${ }^{(3,12)}$.

Effective screening of newborns for CF using dried-blood specimens collected at birth, combined with follow-up diagnostic studies and treatment, helps to prevent premature death ${ }^{(4)}$. In 1979, the development of a test to measure immunoreactive trypsinogen (IRT) in dried blood spots, which is usually substantially elevated in newborns with $\mathrm{CF}$, made universal newborn screening for $\mathrm{CF}$ feasible ${ }^{(5,6)}$. The two most common protocols for CF screening are (a) measuring IRT on one sample and retesting IRT positive on newly collected specimen, and (b) IRT testing followed by DNA mutation analysis on the same sample for positive cases ${ }^{(14)}$.

In Brazil, time-resolved fluorescence immunoassay is the method approved by the Health State Department for CF newborn screening. Therefore, the aim of this study was to validate the AutoDELFIA ${ }^{\circledR}$ Neonatal IRT kit in dried blood spots from Guthrie cards.

\section{MATERIALS AND METHODS}

IRT was measured in neonatal dried blood spots (Guthrie cards) by a time resolved immunofluorometric assay (AutoDELFIA ${ }^{\circledR}$ Neonatal IRT - PerkinElmer Life and Analytical Sciences, Wallac Oy, Mustionkatu 6, Turku, Finland) on AutoDELFIA (PerkinElmer)

First submission on 22/04/13; last submission on 10/05/13; accepted for publication on 18/06/13; published on 20/12/13

1. Biochemist at Universidade Federal do Rio Grande do Sul-Pharmacy School (UFRGS).

2. Biologist at Laboratório de Triagem Neonatal do Rio Grande do Sul.

3. PhD in biochemistry by UFRGS; professor at UFRGS-Pharmacy School; technically reponsible for Laboratório de Triagem Neonatal do Rio Grande do Sul. 
equipment. This study was conducted at the Reference Newborn Screening Laboratory of Rio Grande do Sul, South of Brazil (Laboratório de Triagem Neonatal do Rio Grande do Sul).

AutoDELFIA ${ }^{\circledR}$ Neonatal IRT assay is a two-site sandwich immunoassay that utilizes two purified mouse monoclonal antibodies for capture and detection of IRT. Punched dried blood spots samples are eluted in microtitration plates coated with immunoglobulin $\mathrm{G}(\mathrm{IgG})$ anti-IRT monoclonal antibody. Subsequently, a second $\operatorname{Ig} G$ anti-IRT antibody conjugated to europium is added. After incubation, a fluorescent reaction occurs following addition of the intensifier reagent. The fluorescence signal is proportional to the concentration of IRT present in the sample.

For validation, we evaluated 21 samples collected in standardized filter paper (Schleicher and Schuell \#903). Proper blood collection procedures were observed.

To determine the inaccuracy, a comparative study was performed. Twenty specimens analysed by the same method were selected from another newborn screening laboratory. Considering an ITR cut-off value of $70 \mathrm{ng} / \mathrm{ml}, 16$ samples were positive and 4 samples were negative. Correlation coefficient was calculated.

To determine the within-assay precision, a replication experiment was performed by obtaining test results from 20 samples of the same material, in a run. In the between-assay, this specimen was analyzed in quadruplicate, once a day, for 5 days. Mean, standard deviation (SD) and coefficient of variation (CV) were calculated.

We used EP-Evaluator software (version 9) for statistical evaluation of the results. The random error (RE), systematic error (SE) and analytical error (AR) were estimated.

\section{RESULTS}

In the accuracy study, the correlation coefficient was 0.9459 . Considering an allowable total error (TEa) of $30 \%$ for each specimen and a medical decision point (MDP) of $70 \mathrm{ng} / \mathrm{ml}$, a scatter plot is showed in Figure. The average error index (Y-X)/ TEa was $-0.12 \mathrm{ng} / \mathrm{ml}$, with a range of -0.75 to $0.62 \mathrm{ng} / \mathrm{ml}$. The largest error index occurred at $93.8 \mathrm{ng} / \mathrm{ml}$ concentration.

In the within-assay precision, we obtained a mean value of $4.3 \mathrm{ng} / \mathrm{ml}$, standard deviation of $0.49 \mathrm{ng} / \mathrm{ml}$, and coefficient of variation of $11.36 \%$. In the between-assay precision, mean was $3.95 \mathrm{ng} / \mathrm{ml}, \mathrm{SD}=0.26 \mathrm{ng} / \mathrm{ml}$ and $\mathrm{CV}=6.65 \% . \mathrm{RE}=26.61 \%, \mathrm{SE}=$ $4.95 \%$ and $\mathrm{AR}=31.51 \%$.

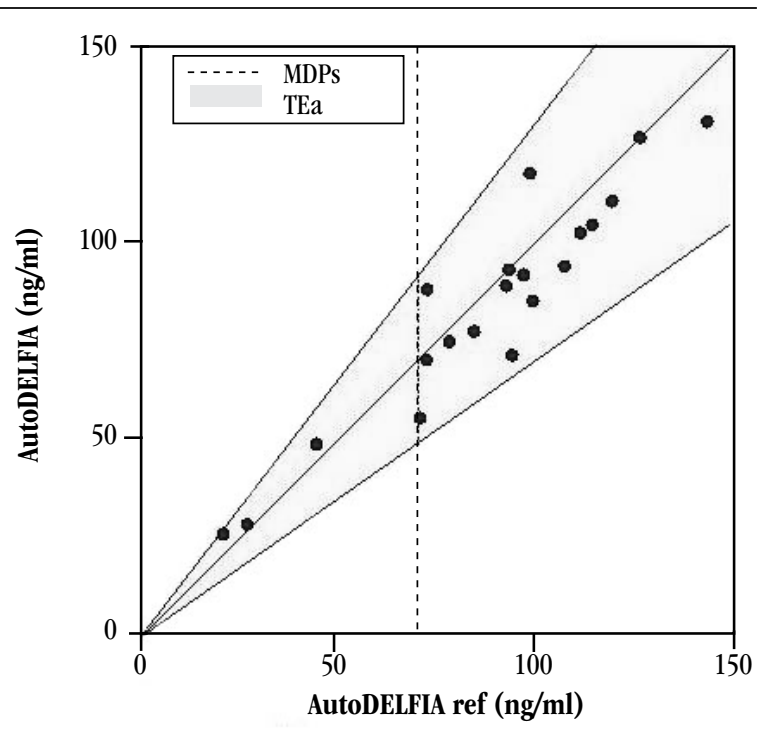

FIGURE - Scatter plot of AutoDELFIA comparative versus AutoDELFIA ${ }^{\circledR}$ reference TEa: allowable total error; MDPs: medical decision point.

\section{DISCUSSION}

We presented the results of the evaluation of IRT Neonatal analytical performance in AutoDELFIA ${ }^{\circledR}$. Previous studies, carried out with different technologies, have demonstrated similar $\mathrm{CV}^{(1,11)}$.

Several factors may contribute to analytic variation in dried blood spot. Hematocrit and blood spot volume effects are some examples. The uniform absorbing properties of the filter paper can be hindered if blood is blotted or smeared onto the paper, or if a drop of blood is placed on top of a previously collected drop. In addition, the volume of whole blood applied to filter paper as a blood spot can influence the volume of serum contained within a single disc punched out of that spot ${ }^{(2,9)}$.

Chromatographic effects are an additional potential source of error. Although previous analyses have documented $<2 \%$ variation in the concentration of absorbed blood taken from various locations within a single blood spot ${ }^{(2,9)}$, specific analytes have been shown to vary across a single spot ${ }^{(8)}$.

Those effects should be considered in the determination of the most appropriate cut-off value in order to avoid an increase in false-negative or false-positive results. To improve the positive predictive value, IRT testing followed by deoxyribonucleic acid (DNA) mutation analysis on the same sample is the best strategy for positive cases ${ }^{(7,10)}$. Moreover, earlier definitive diagnosis should allow earlier therapeutic intervention, genetic counseling, thus alleviating parental distress ${ }^{(2)}$. 


\section{CONCLUSION}

This kit has acceptable performance for neonatal screening routine.
Authors' conflict of interest disclosure

The authors stated that there are no conflicts of interest regarding the publication of this article.

\section{RESUMO}

A triagem neonatal da fibrose cística (FC) é realizada por meio da quantificação da tripsina imunorreativa. 0 objetivo desse estudo foi validar o kit AutoDELFIA® Neonatal immunoreactive trypsinogen. Realizou-se um estudo comparativo entre dois equipamentos. Como resultado, encontrou-se o erro aleatório $=26,6 \%$, erro sistemático $=4,9 \%$ e erro total $=31,5 \%$. Diversos fatores contribuem para a variação dos ensaios em papel filtro, como efeito cromatográfico, efeito do bematócrito e efeito do volume total de sangue. Esses fatores devem sem considerados na avaliação dos resultados da validação. O proposto kit pode ser implantado na rotina de triagem neonatal para FC.

Unitermos: triagem neonatal; fibrose cística; estudos de validação; tripsinogênio.

\section{REFERENCES}

1. CABRINI, G. et al. An evaluation of an enzyme immunoassay method for immunoreactive trypsin in dried blood spots. Clin Biochem, v. 23, p. 213-9, 1990.

2. CASTELLANI, C.et al. European best practice guidelines for cystic fibrosis neonatal screening.J Cyst Fibros, v. 8, p.153-73, 2009.

3. CENTER FOR DISEASE CONTROL AND PREVENTION. Newborn screening for cystic fibrosis: evaluation of benefits and risks and recommendations for state newborn screening programs. $M M W R$, v. 53, n. RR13, p. 1-36, 2004.

4. CHEILLAN, D. et al. False-positive results in neonatal screening for cystic fibrosis based on a three-stage protocol (IRT/DNA/IRT): should we adjust IRT cut-off to ethnic origin? J Inherit Metab Dis, v. 28, p. 813-8, 2005.

5. CROSSLEY, J. R.; ELLIOT, R. B.; SMITH, P. A. Dried-blood spot screening for cystic fibrosis in the newborn. Lancet, v. 1, p. 472-4, 1979.

6. KIRBY, L. T. et al. Use of a dried blood spot in immunoreactive-trypsin assay for detection of cystic fibrosis in infants. Clin Chem, v. 27, n. 15, p. $678-80,1981$
7. MASSIE, R. J. H. et al. Lessons learned from 20 years of newborn screening for cystic fibrosis. Med J Aust, v. 196, p. 67-71, 2012.

8. MCDADE, T. W.; SHELL-DUNCAN, B. Whole blood collected on filter paper provides a minimally invasive method for assessing human transferrin receptor level.J Nutr, v. 132, p. 3760-3, 2002.

9. MEI, J. V. et al. Use of filter paper for the collection and analysis of human whole blood specimens. J Nutr, v. 131, p. S1631-6, 2001.

10. PITT, J. J. Newborn screening. Clin Biochem, v. 31, p. 57-68, 2010.

11. RYALL, R. C. et al. Modifying an enzyme lmmunoassay of Immunoreactive trypsinogen to use time-resolved fluorescence. Clin Chem, v. 39, n. 2, p. 224-8, 1993.

12. SERMERT-GAUDELUS, I. et al. The CF-CIRC study: a French collaborative study to assess the accuracy of cystic fibrosis diagnosis in neonatal screening. BMC Pediatr, v. 6, n. 25, 2006. Disponível em: $<$ http://www.biomedcentral.com/1471-2431/6/25>. Acesso em: 21 set. 2010.

13. SOUZA, C. F. M.; SCHWARTZ, I. V.; GIUGLIANI. R. Triagem neonatal de distúrbios metabólicos. Ciênc Saúde Coletiva, v. 7, n. 1, p. 129-37, 2002.

14. WANG, L.; FREEDMAN, S. D. Laboratory tests for the diagnosis of cystic fibrosis. Am J Clin Pathol, v. 117, suppl.1, p. S109-15, 2002.

\section{MAILING ADDRESS}

Simone Martins de Castro

Faculdade de Farmácia; Universidade Federal do Rio Grande do Sul; Av. Ipiranga, 2752, sala 304B; Santana; CEP: 90610-000; Porto Alegre-RS, Brazil; e-mail: scastro@adufrgs.ufrgs.br.. 